\title{
Comparative Analysis of Effects of Seed Biopriming on Growth and Development in Different Pulses: Pea, Lentil, Red Gram and Chickpea
}

\author{
Shweta Meshram* and Birinchi Sarma \\ Mycology and Plant Pathology, IAS, Banaras Hindu University, Varanasi-221 005, (U.P.), India \\ *Corresponding author
}

A B S T R A C T

\section{Keywords}

Trichoderma spp, Seed treatment, Pea, Lentil, Red gram, Chickpea.

\section{Article Info}

Accepted: 23 September 2017 Available Online: 10 October 2017
Pulses are economically and nutritionally important crop in India. It continuously faces biotic and abiotic challenges. In this study we analysed the potentiality of Trichoderma spp. in germination and development of pulses. The pulse crops were taken as Pea, Lentil, chickpea and Red gram. All pulse seeds were treated with Trichoderma spp. suspension before sowing. We analysed the effect under parameters such as germination, total average length. Total average root and shoot length individually to check the effect of treatments in growth promotion of root and shoot. Fresh weight and dry weight was also recorded to observe more response of treatment on plants. All treatments were tested against a control which is untreated. Significant difference was observed in response of treatment between treated and untreated plants. It is showing positive effect on growth and development of plants under above parameter. These results will help in exploring more in the future.

\section{Introduction}

Pea (Pisum sativum) is highly protein rich and nutritional crop of India. It is consumed as vegetable as well as spilt grains are utilized as dal. Straw is also used as fodder for cattle. It's a cool season or rabi crop and reported to be first crop grown by human civilization (Dhanraj Patel et al., 2017). It experience many stresses which effect its productivity like freezing stress, reduced pod yield (Zhang et al., 2016). Lentil (Lens culinaris) commonly known as masoor. It is a high fiber and contains $23.7 \%$ protein (Dahal et al., 2017) provides ample amounts of essential amino acids for development of body (Yadav et al., 2007). It's frequently exposed with lot diseases such as Aschochyta blight, anthracnose or soil born disease like sclerotinia white mold (Agrios, 2005).

Pigeonpea (Cajanus cajan) is one of the major grain legume (pulse) crops of tropics and sub-tropics. It has capacity to recycle the soil fertility by fixing atmospheric nitrogen (Reddy et al., 1990). The protein content of dry split pigeonpea grains (dal) is about 24 percent (Singh et al., 1993). The crop is plagued by various diseases of fungal, nematode, viral and bacterial origins (Kannaiyan et al., 1984; Nene et al., 1989). Chickpea (Cicer arietinum) third in the world 
among pulse crops after peas and beans with an area of 6.3 million hectare with an average yield of 7330 thousand tonnes (Agricoop, 2014-15). It is faces challenges against many pathogen in which soli born diseases are more sever such as fusarium wilt, sclerotinia rot, sclerotium disease etc. (Bhatti et al., 1992). 9$41 \%$ yield loss has been reported in chickpea (Pandey et al., 2017).

The application of Trichoderma species can control a large number of foliar and soil borne fungi i.e. Fusarium spp., R. solani, Pythium spp., S. sclerotiorum, $S$. rolfsii, in vegetables, field, fruit and industrial crops (Tran, 1998; Ngo et al., 2006). Application of Trichoderma enhances the antioxidant activity which perform best against stress condition mostly in case of biotic stress (Sing et al., 2013). It's also reported that mortality rate is less under Trichoderma application (Singh et. al.2014). It has strong biocontrol, mycoparasitic and enzymatic activity against pathogens (Mohiddin et al., 2010) thus having strong capacity to manage above diseases. It's also compatible with other fungicides.

Trichoderma spp. can promote growth of plants significantly (Zhang et al., 2016). In our study we focused on growth promoting property of Trichoderma spp. on different pulses to check whether the different crop respond differently to treatment? And do all pulse crops shows positive effect of treatments. We took 4 crops pea, lentil, Red gram and chickpea. Seeds were pre-treated with Trichoderma culture and then studied for various aspects. We got following significant results.

\section{Materials and Methods}

\section{Preparation of culture}

Pure culture of Trichoderma spp. was prepared (Fig. 1). Seeds were treated when culture developed fully and sporulation was observed on $6^{\text {th }}$ day after inoculation on PDA plate. Culture was diluted with distilled water and seeds were soaked mixing CMC solution for proper adhesion of Trichoderma fungus on seeds. It was soaked for 4-5 hrs then sown on pots filled with sterile soil and grown under controlled condition in green house.

\section{Germination test}

Observations were taken 6 days after sowing and second observation was taken on $10^{\text {th }}$ day after sowing. Two replication of control was taken and three replications of treatments were taken. Observation was taken for each pot and value was averaged for both treatment and control.

\section{Average total length}

Average total length was recorded in cms. First observation was taken on $8^{\text {th }}$ day after sowing and then it was repeated at interval of four days for four times.

\section{Total average root and shoot length}

Average root and shoot length were recorded in $\mathrm{cms} 23^{\text {rd }}$ days after sowing by uprooting the plants from the plants.

\section{Measuring fresh weight and dry weight}

Immediately after uprooting of plants on $23^{\text {rd }}$ day, fresh weight measured on electronic balance in gms. Dry weight measured for oven dried sample $\left(60^{\circ} \mathrm{C}\right.$, overnight $)$.

\section{Results and Discussion}

\section{Test of germination}

Average of germination for crops, pea, lentil, red gram and chickpea were taken. These crops were sown with treatment and without treatment of seeds under controlled condition. 
Highest germination was observed in pea and chickpea among treated and control whereas lowest vale is 7.33 for chickpea under control which is without Trichiderma spp. treatment.

\section{Average total length}

Treated plants showed more average length than the untreated plants.

We observed that all seeds for which pre sowing treatment was given with Tirchoderma spp. was showing enhanced germination than control (Table 1). It shows that priming with Trichoderma prior to sowing, giving positive effect on germination. Whereas we also observed that among pulses response to the treatment varies 8.66 to 9.33 ranges. Shows that different pulse species have different impact of seed treatment on germination however it is observed positive than the control in all pulses.

On the total length of the plants if we see individually for each crop we can observe that growth has been enhanced and it was recorded since starting of observation. Treated plants are showing more length than control plants in each crop. On the 4rth observation lentil is showing more growth difference in treated condition against control. Other pulses such as pea, Red gram and chickpea also observed to positively correlated with the treatments of Trichoderma as these are also showing enhanced growth under treated condition against control (Table 2).

It is interesting that effects of treatment not only enhanced total length or just shoot length; it has significantly promoted the root length in each pulse crop, which is important factor in all pulse crops. It will not only increase the vigour and growth of plants but also the capacity to tolerate biotic and abiotic stresses (Table 3). Difference in root length is recorded highest for lentil followed by chickpea. Fresh weight and dry weight both were recorded high in treated sample compare to the control (Table 5 and 6).

It is very positive indication that treatment can bring good vigour in plants and promotes both root and shoot growth. Root growth observed to be more promoted (Table 4).

Fig.1 Pure culture of Trichoderma spp. used for seed treatment

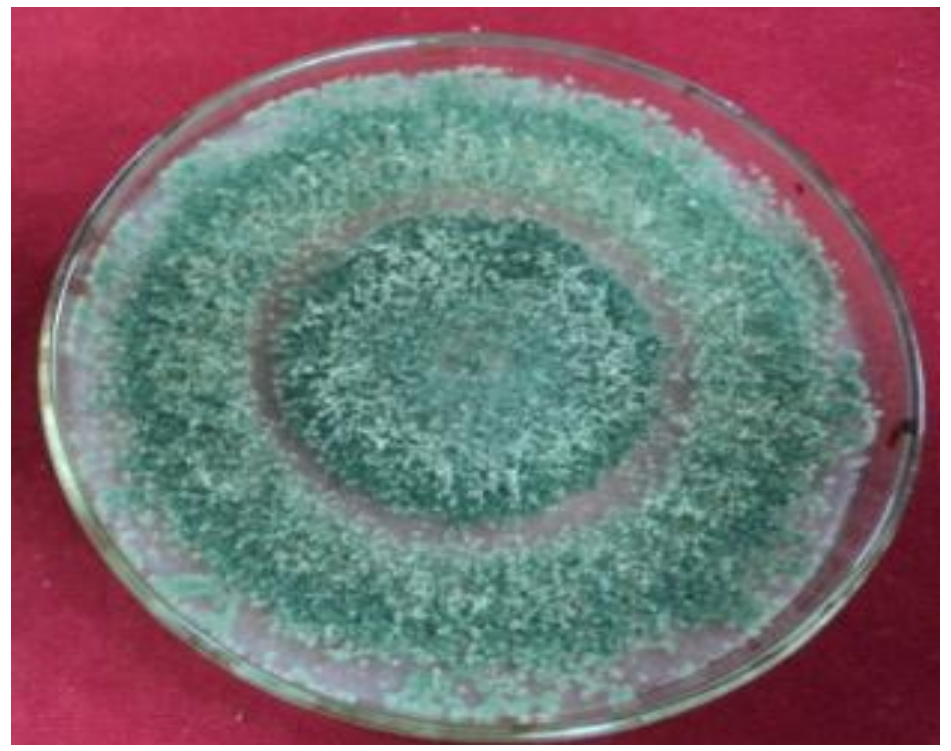


Table.1 Average numbers of germinated seeds in pots

\begin{tabular}{|l|c|c|}
\hline Name of crop & Average value of control & Average value of treatments \\
\hline Pea & 7.66 & 9.33 \\
\hline lentil & 8.33 & 9 \\
\hline Red gram & 8 & 8.66 \\
\hline Chickpea & 7.33 & 9.33 \\
\hline
\end{tabular}

Table.2 Average total length of plants in pots obtained and observation was recorded at 4 days of interval from sowing date

\begin{tabular}{|l|c|c|c|c|}
\hline Name of crop & $\begin{array}{c}\text { Average value of } \\
\text { Ist observation } \\
(\mathrm{cms})\end{array}$ & $\begin{array}{c}\text { Average value of } \\
\text { 2nd observation } \\
(\mathrm{cms})\end{array}$ & $\begin{array}{c}\text { Average value of } \\
\text { 3rd observation } \\
(\mathrm{cms})\end{array}$ & $\begin{array}{c}\text { Average value of } \\
4^{\text {th }} \text { observation } \\
(\mathrm{cms})\end{array}$ \\
\hline Pea & & & & 4.70 \\
\hline Control & 1.37 & 2.96 & 4.70 & 6.43 \\
\hline treatment & 2.11 & 3.21 & & 10 \\
\hline Lentil & & & 8.50 & 11.80 \\
\hline control & 2.50 & 5.56 & 8.74 & 7.33 \\
\hline Treatment & 2.73 & 6.65 & 6.16 & 8.35 \\
\hline Red gram & & & 7.07 & 7.5 \\
\hline control & 1.33 & 3.80 & & 8.6 \\
\hline Treatment & 1.70 & 4.65 & 6.86 & \\
\hline chickpea & & & 7.33 & \\
\hline control & 2.88 & 4.5 & & \\
\hline Treatment & 2.96 & 5.2 & & \\
\hline
\end{tabular}

Table.3 Total average root length was recorded on $23^{\text {rd }}$ days after sowing

\begin{tabular}{|l|c|c|}
\hline Name of crop & $\begin{array}{c}\text { Average value of control } \\
(\mathrm{cms})\end{array}$ & $\begin{array}{c}\text { Average value of } \\
\text { treatments(cms })\end{array}$ \\
\hline Pea & 6.50 & 11.83 \\
\hline lentil & 12.75 & 13.00 \\
\hline Red gram & 10.50 & 15.08 \\
\hline Chickpea & 10.23 & 12.25 \\
\hline
\end{tabular}

Table.4 Total average shoot length was recorded on $23^{\text {rd }}$ days after sowing

\begin{tabular}{|l|c|c|}
\hline Name of crop & $\begin{array}{c}\text { Average value of } \\
\text { control(cms })\end{array}$ & $\begin{array}{c}\text { Average value of } \\
\text { treatments(cms })\end{array}$ \\
\hline Pea & 9 & 9.43 \\
\hline lentil & 11.3 & 13.21 \\
\hline Red gram & 10.90 & 11.25 \\
\hline Chickpea & 10.60 & 12.31 \\
\hline
\end{tabular}


Table.5 Average dry matter in gms

\begin{tabular}{|l|c|c|c|c|}
\hline Name of crop & \multicolumn{2}{|c|}{ Root } & \multicolumn{2}{c|}{ Shoot } \\
\hline & Control & Replication & Control & Replication \\
\hline pea & 0.20 & 0.22 & 0.31 & 0.38 \\
\hline lentil & 0.057 & 0.066 & 0.086 & 0.15 \\
\hline Red gram & 0.28 & 0.33 & 0.32 & 0.37 \\
\hline chickpea & 0.17 & 0.22 & 0.34 & 0.38 \\
\hline
\end{tabular}

Table.6 Average fresh matter in gms

\begin{tabular}{|l|c|c|c|c|}
\hline Name of crop & \multicolumn{2}{|c|}{ Root } & \multicolumn{2}{c|}{ Shoot } \\
\hline & Control & Replication & Control & Replication \\
\hline pea & 1.33 & 2.65 & 2.51 & 3.37 \\
\hline lentil & 0.23 & 0.25 & 0.64 & 0.78 \\
\hline Red gram & 2.23 & 2.29 & 1.39 & 2.16 \\
\hline chickpea & 2.2 & 2.73 & 2.07 & 2.85 \\
\hline
\end{tabular}

Seed treatment of pulse seeds with the, resulted in enhanced growth over the normal sown seed. It can help in increasing vigour of plants. Increased vigour can make plants able to tolerate abiotic stress such as drought and salt tolerance.

In view of biotic stress it can make plants tolerant for soli borne diseases such as Fusarium wilt, Sclerotonia rot by its antagonistic and competitive ability, also to withstand against insect injury.

In some cases it also been reported that the treatment with Trichoderma can induce defence response (Benítez et al., 2004). It only provides plant defense against microbial stress but also respond well to salt stress (Brotman et al., 2013).

It can be further explored for the other crops and studying the nature of disease/tolerance resistance in crops. Especially for soil and root pathogen because growth promotion is more compare to untreated seeds. Other than pulse crops also it can be useful treating seed with Trichoderma, for growth promotion and disease tolerance as it is not a costly affair.

\section{Future prospects}

Trichoderma is widely present, its isolation and culturing is less tedious (Howell, 2003), thus making this biocontrol agent more accessible. It can be applied in mixed cropping pulses along with cereals, which will increase soil fertility better than the unprimed crops. It compatible with most of the chemicals (Bhai and Thomas, 2010) hence, it can be successfully utilize with other pesticides and fertilizers thus will reduce cost of cultivation. Most importantly it is also compatible with the other biocontrol microorganism in consortium (Singh et al., 2012) and this property can be explored as further in crop protection programmes.

\section{Acknowledgments}

The authors are grateful to the head of the department, department of Mycology and Plant pathology, Institute of Agricultural sciences, as well as higher authorities of the Banaras Hindu University (Varanasi, U.P.) for providing necessary facilities for research work and is dully acknowledge. 


\section{References}

Agricoop. 2014-2015. Chickpea. http://agricoop.nic.in/Annualreport2014 15/EnglishAR2732015.pdf.

Agrios, G. N., 2005. Plant diseases caused by fungi. Plant pathology, 4.

Benítez, T., Rincón, A. M., Limón, M. C., and Codón, A. C. 2004. Biocontrol mechanisms of Trichoderma strains. International microbiology, 7(4), 249260.

Bhatti M.A., and Kraft J.M. 1992. Effects of inoculum density and temperature on root rot and wilt of chickpea. Plant Disease. 76:50-54.

Brotman, Y., Landau, U., Cuadros-Inostroza, Á, Takayuki, T., Fernie, A. R., Chet, I., and Willmitzer, L. 2013. Trichodermaplant root colonization: escaping early plant defense responses and activation of the antioxidant machinery for saline stress tolerance. PLoS pathogens, 9(3), e1003221.

Dahal, D., Ghosh, J., and Chhetri, B. 2017. Impact of Chemical Free BioAccelerated Climate Resilient Cropping on Lentil (Lens culinaris Medic.) Growth and Yield against Conventional Farming System under Rainfed Condition. Int. J. Curr. Microbiol. App. Sci, 6(2), 1004-1015.

Howell, C. R., 2003. Mechanisms employed by Trichoderma species in the biological control of plant diseases: the history and evolution of current concepts. Plant disease, 87(1), 4-10.

Kannaiyan, J., YL Nene, MV Reddy, JG Ryan, TN Raju. 1984. Prevalence of pigeonpea diseases and associated crop losses in Asia, Africa and the Americas. Tropical Pest Manage. 30:62-71.

Kumar, P., and Mane, S. S. 2017. Studies on the Compatibility of Biocontrol Agents with Certain Fungicides. Int. J. Curr. Microbiol. App. Sci, 6(3), 1639-1644.
Mohiddin Khan, M. R., and Khan, S. M. 2010. Why Trichoderma is considered superhero (super fungus) against the evil parasites? Plant Pathol. J., 9: 92102.

Ngo B.H., Vu D.N. and Tran D.Q. 2006. Analyze antagonist effects of Trichoderma spp. for controlling southern stem rot caused by Sclerotium rolfsii on peanut. Plant Protection 1:1214.

Pandey, R. N., Gohel, N. M., and Jaisani, P. 2017. Management of Wilt and Root Rot of Chickpea caused by Fusarium oxysporum f. sp. ciceri and Macrophomina phaseolina through Seed Biopriming and Soil Application of Bio-Agents. Int. J. Curr. Microbiol. App. Sci, 6(5), 2516-2522.

Patel, D., Mehra, J. P., Malviya, D., Singh, S., and Baraiya, B. R. 2017. MorphoPhysiological Traits and Productivity on Garden Pea (Pisum sativum L.) As Influenced by Various Methods of Application of Potassium Humate 4.5. Int. J. Curr. Microbiol. App. Sci, 6(2), 1759-1764.

Reddy, M.V., YL Nene, J Kannaiyan, TN Raju, VN Saka, AT Davor, WP Songa and $\mathrm{P}$ Omanga. 1990. Pigeonpea lines resistant to wilt in Kenya and Malawi. International Pigeonpea Newsletter 6:34.

Singh, F., et al., 1993. Nutritive value and uses of pigeonpea and groundnut. Human resource development program, skill development. Series No.14. ICRISAT.

Singh, A., Jain, A., Sarma, B. K., Upadhyay, R. S., and Singh, H. B. 2014. Rhizosphere competent microbial consortium mediates rapid changes in phenolic profiles in chickpea during Sclerotium rolfsii infection. Microbiological research, 169(5), 353360. 
Singh, A., Sarma, B. K., Upadhyay, R. S., and Singh, H. B. 2013. Compatible rhizosphere microbes mediated alleviation of biotic stress in chickpea through enhanced antioxidant and phenylpropanoid activities. Micro biological Research, 168(1), 33-40.

Singh, S. P., Singh, H. B., and Singh, D. K. 2013. Trichoderma harzianum and Pseudomonas sp. Mediated management of Sclerotium rolfsii rot in tomato (Lycopersicon esculentum Mill.). Life sciences, 8(3), 801-804.

Suseela Bhai, R., and Thomas, J. 2010. Compatibility of Trichoderma harzianum (Ritai.) with fungicides, insecticides and fertilizers. Indian Phytopathology, 63(2), 145-148.
Yadav, S. S., McNeil, D. L., and Stevenson, P. C. (Eds.). 2007. Lentil: An ancient crop for modern times. Springer Science and Business Media.

Zhang, S., Gan, Y., and Xu, B. 2016. Application of plant-growth-promoting fungi Trichoderma longibrachiatum T6 enhances tolerance of wheat to salt stress through improvement of antioxidative defense system and gene expression. Frontiers in plant science, 7.

Zhang, X., Wan, S., Hao, J., Hu, J., Yang, T., and Zong, X. 2016. Large-scale evaluation of pea (Pisum sativum L.) germplasm for cold tolerance in the field during winter in Qingdao. The Crop Journal, 4(5), 377-383.

\section{How to cite this article:}

Shweta Meshram and Birinchi Sarma. 2017. Comparative Analysis of Effects of Seed Biopriming on Growth and Development in Different Pulses: Pea, Lentil, Red Gram and Chickpea. Int.J.Curr.Microbiol.App.Sci. 6(10): 2944-2950. doi: https://doi.org/10.20546/ijcmas.2017.610.347 